\title{
17
}

\section{Stora Karlsö - a tiny Baltic island with a puzzling past}

\author{
Rita Larje \\ Swedish Museum of Natural History, Stockholm, Sweden \\ larita00@hotmail.com
}

\section{Introduction}

In the middle of the Baltic Sea, about $75 \mathrm{~km}$ from the Swedish mainland, lies the Swedish island Gotland. On its west coast are three small islands, the two Karlsö islands and the Västergarn islet. The largest island, Stora Karlsö, is $6.5 \mathrm{~km}$ from the west coast of Gotland, and is a nature reservation owned by a non-profit shareholders' association, the Karlsö Hunting and Animal Protection Association, founded in 1880 on the initiative of Willy Wöhler, a farmer from Gotland. The island is about $2.5 \mathrm{~km}^{2}$ in size and about $1 \mathrm{~km}$ wide (north-south) and $2 \mathrm{~km}$ long (east-west), with the highest point $51.6 \mathrm{~m}$ above sea level. For such a small island, prehistoric remains are exceedingly abundant. From an elevated point in the centre of the island, you can visually travel in time over the landscape from Middle Neolithic, to later prehistoric, to historic sites (Figure 1).

\section{The making of an island}

Understanding the formation of Stora Karlsö is important for understanding the distribution and location of prehistoric sites, particularly those associated with early human occupation. The bedrock is coral reef that was transformed into limestone. There are steep cliffs towards the sea on all sides of the island, except to the south, where the limestone strata has a downward slope. Between the cliffs in the north is a good harbour. The landscape configuration is a result of erosion. The general outline was created by the erosive force of a thick ice cap that covered the Baltic basin during the last glaciation. After the ice melted some 12,000 years ago, Stora Karlsö was submerged, but with the pressure of the heavy ice gone, the land began to rise quickly. Once the island emerged, it was exposed to the force of sea waves. Fresh-water lakes and saltwater seas alternated in the Baltic basin and during this time, the water level varied greatly. The sea waves created the intricate coastal outline of the island, flushed away loose soil, scraped out caves and built up beach ridges. These processes left a plateau island divided by a broad valley with a north-south extension that was crossed by two large beach ridges. The oldest, the Ancylus ridge, 


\section{STORA KARLSÖ}

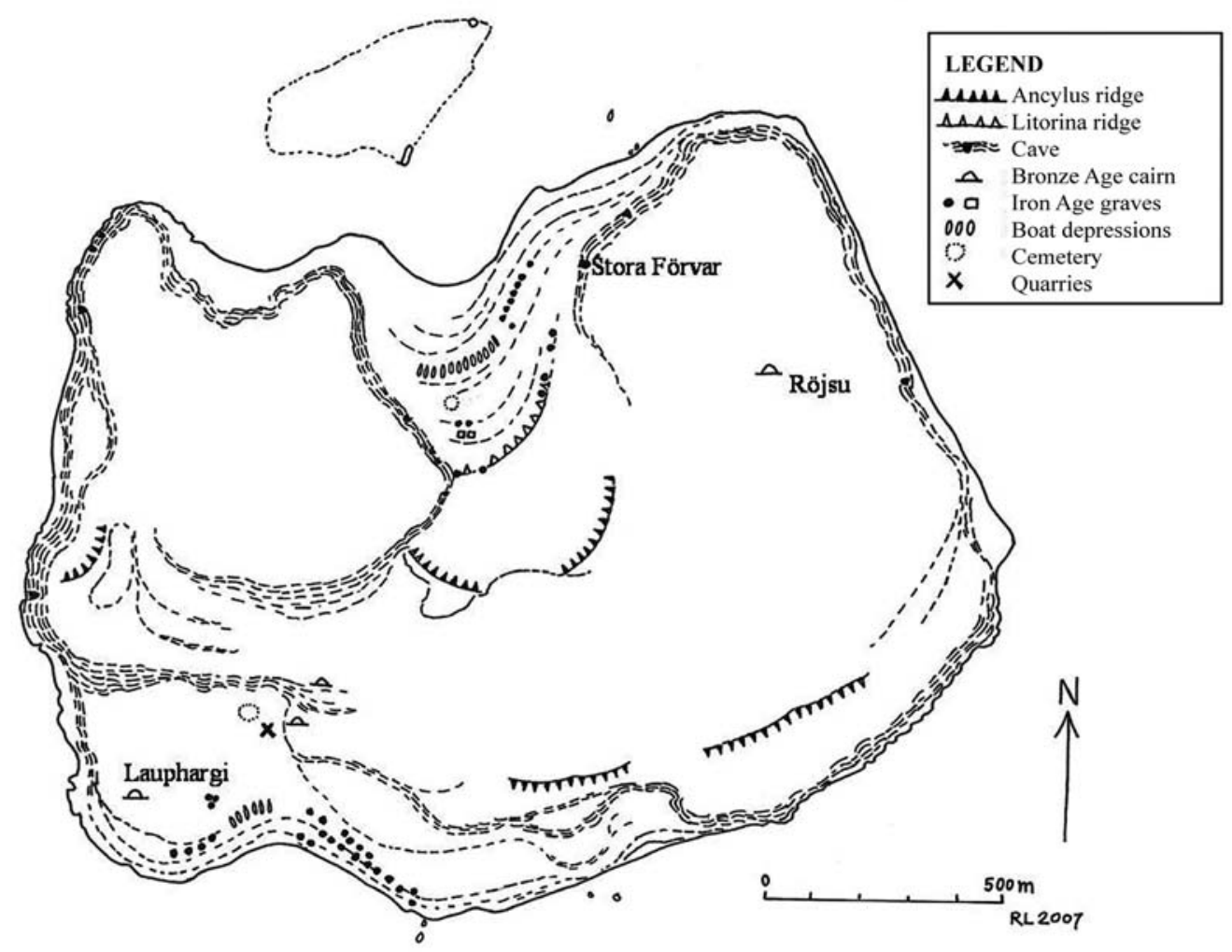

Figure 1. Map of Stora Karlsö showing the location of prehistoric monuments.

formed in a fresh-water lake 10,700-10,000 years ago and is now $28 \mathrm{~m}$ above sea level (Munthe et al. 1927). The melting ice cap led to a rise in the sea level that exceeded at times the rate of land emergence, with sea levels rising as much as $5-10 \mathrm{~cm}$ a year.

Finally, the Ancylus Lake was forced to find a new outlet in the south. Within only 200 years, the water level sank to the ocean level and saltwater filled the Baltic basin. The Ancylus Lake was replaced with a saltwater body, the Litorina Sea, which lasted for about 7000 years. This sea had six transgressions, the last and highest about 6000 BP. The Litorina maximum formed another beach ridge on Stora Karlsö that is now 18-20 m above sea level. The formation of beach ridges is still in progress in the Limnea Sea, the 'modern' Baltic Sea.

In the past, the Karlsö islands were named Foulleholmene (the Bird Islands), a name easily understood given the presence of thousands of guillemots (Aria aalge) and razorbills (Alca torda) which nest on the cliff walls and rocky shores on both islands. All the islands are rich in sea birds, and land birds also nest there. In prehistory, hunters and fishermen made the most of island resources such as seals, birds, eggs and fish. Stora Karlsö was never thickly forested and there was good grazing without the need for forest clearing.

\section{Stora Förvar cave: The start of human impact}

Humans first set foot on the island about 9500 years ago, according to evidence found in the Stora Förvar (large storage) cave in the cliff wall of the eastern plate. Numerous bone remains and artefacts were uncovered in 1887 , and the discovery led to a five-year excavation campaign 
under the direction of Lars Kolmodin and Hjalmar Stolpe between 1888 and 1893. The cave was created by the Ancylus Lake and is about $25 \mathrm{~m}$ deep. The entrance is some $21 \mathrm{~m}$ above sea level and is $9.5 \mathrm{~m}$ wide and $6.5 \mathrm{~m}$ high. The cave narrows from the entrance and the floor has an upward slope to the interior (Figure 2).

The excavation of Stora Förvar in the late 19th century uncovered a cultural layer more than $4 \mathrm{~m}$ deep, producing six tons of animal bone, some human remains, bone and stone artefacts and a multitude of potsherds. The deposit spanned the Mesolithic to Iron Age. Excavation was carried out in $30 \mathrm{~cm}$ layers over defined horizontal areas, labelled Area A to Area I. No consideration was taken of the stratigraphy of the sloping floor, which reduces the possibility of accurately dating particular layers. This means that cultural finds from a particular area and depth are not necessarily contemporary with those excavated from the same depth in another area.

The excavation produced a huge quantity of material to analyse, but both Kolmodin and Stolpe died in 1905 without finishing the work. The task was then entrusted to Bror Schnittger, who, in 1913, published the description of the cave and the excavations, but who did not publish on the cultural material.

Some animal bones from Stora Förvar were analysed by A. Pira and C.O. Roth, and C. Fürst examined the human remains from the cave. Unfortunately, all three died before finishing their studies. Pira's work on the pig remains from the cave was published in 1909 and another general study of the bone remains was published posthumously in 1926. When Schnittger died in 1924, the responsibility for the excavated material was given to Schnittger's widow, Hanna

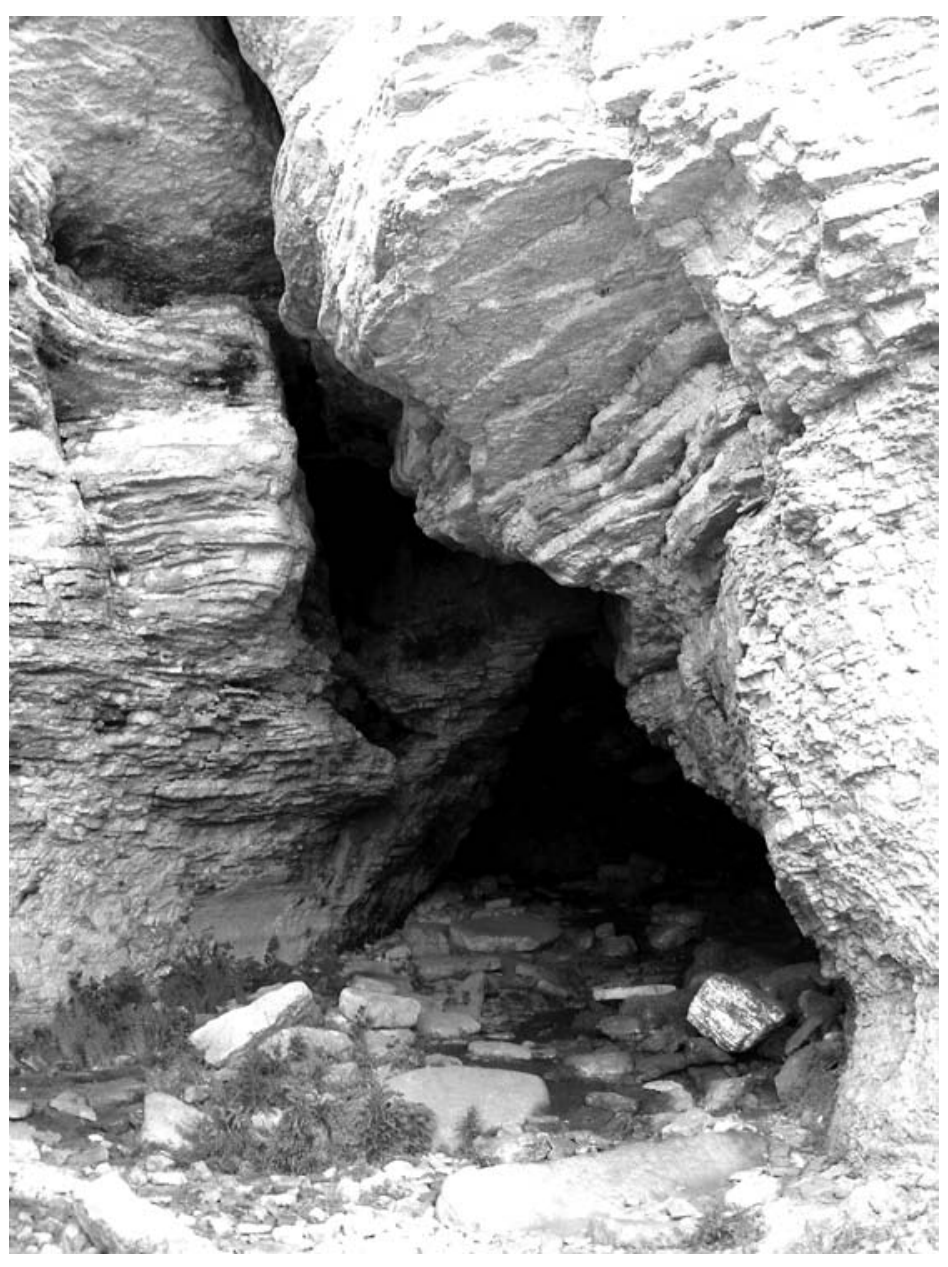

Figure 2. Stora Förvar, the cave entrance (photo by R. Larje). 
Rydh. In 1931, she published an outline of the prehistory of Stora Karlsö, which also gave a survey of the archaeological studies, and included Roth's list of bird species identified from the cave. Rydh decided to publish an analysis of the cave artefacts together with a revised version of Schnittger's 1913 publication. The analysis of bones had to be postponed. The publication was finished in 1940 (Schnittger and Rydh 1940), and included an extensive catalogue of the cave finds.

Subsequently, several archaeozoologists could not resist the temptation offered by the six tons of bone remains collected from Stora Förvar material. Erikson and Knape (1991) used bones from Area $\mathrm{F}$ in the middle of the cave to study occupation seasonality. Lindqvist and Possnert (1997) included Stora Förvar in an accelerator mass spectrometry (AMS) ${ }^{14} \mathrm{C}$ dating project to date the original occupation of Gotland, as extensive ${ }^{14} \mathrm{C}$ dating could overcome the chronological problem created by the poor recording of excavation stratigraphy. Johansson and Larje (1993) analysed a soil sample from the cave and verified that the 19th century excavation by 'spade and knife' had missed many of the smaller cultural remains.

In 1889, human skulls and associated splintered long bones found deep in Area D were interpreted to be the result of cannibalism or a ritual ancestor cult (Retzius 1890; Rydh 1931). The cannibalism theory was not proven, and is still under investigation. The human bones were unfortunately lost, but more human remains were found by Lindqvist (1996) in the analysis of bone from excavation Area G. The Area G remains comprised some 50 bones from more than five individuals: a baby two to four months old, a young teenager, an older teenage boy, an adult woman and probably two adult men. The bones came from the oldest, pre-ceramic layers, and AMS dating (Lindqvist and Possnert 1997) places the baby and the boy in the Late Mesolithic (Boreal) period (c. 9500 to $8200 \mathrm{cal}$. BP). This makes these remains the oldest humans found on Gotland to date (Lindqvist 1996). A burnt fragmentary human frontal skull bone with numerous cut marks raised again the question of ritual behaviour. The way the human bones were scattered and mixed with animal-bone refuse, artefacts and ashes was taken as an indication of cult activity. The question of 'cult' behaviour can be examined further in the study of human bone from the unanalysed excavation areas. The catalogue published in Schnittger and Rydh (1940) mentions human remains in various areas and from various layers, but does not mention the presence of intact human burials.

\section{Mesolithic subsistence strategy}

The Mesolithic economy was based largely on grey-seal and ringed-seal hunting. An occasional mountain hare was on the menu, as indicated by sparse hare bones, together with birds and fish. The Baltic Basin was a fresh-water lake that only gradually became more brackish from about 9200-9000 cal. BP (Lindqvist and Possnert 1997). Bones of Whooper swan (Cygnus cygnus) and a number of ducks were found, but no auks. It is likely the cliffs of Stora Karlsö swarmed with birds in the past, as today (Stora 2006). The most common fish caught was salmon. The climate at this time was mild, with a mean temperature higher than today, and the island was covered with open woodland of pine and hazel (Eriksson 1988, 1992).

Ericson and Knape (1991) found that grey-seal bones in the pre-ceramic layers in Area $\mathrm{H}$ were from young animals, nearly six months old, as indicated by mandible length. These researchers are of the opinion that Stora Karlsö was a seasonal seal-hunting station and the Stora Förvar cave was used as a refuse dump for seal-cub carcasses. The seal hunting, mainly done with nets, was primarily for skins, based on the scarcity of metacarpals and metatarsals, and the way some mandibles were chopped, consistent with skinning. Lindqvist (1991) assessed the age range of the seals, from the length of the molar row, as from one to four months in the early 
layers of Area G. Assuming the cubs were born on ice in early March, as is the case in the Baltic today (Roos 2000), six-month-old cubs could be caught at the earliest in August-September. Seal cubs born in March and killed aged from one to four months would have been hunted between April and May. This suggests a non-winter season for hunting in both cases.

Lindqvist and Possnert (1997) discuss the introduction of grey seals in the Baltic Basin and note the adaptability of the animals' reproduction strategy. AMS ${ }^{14} \mathrm{C}$ dating of grey seals in the bottom layers of Area $G$ to the early Mesolithic probably implies entry from the south during the Yoldia Sea stage before 9600 BP. The adaptable grey seal could have endured the fresh-water Ancylus Lake stage of the Baltic and changed its reproduction strategy from autumn birth on shores in the west Atlantic, to spring birth on ice in the Baltic.

Whereas Ericson and Knape (1990) argue in favour of a seasonal hunting station, Lindqvist (1996) suggested a more permanent occupation. He based this on the estimated age of the human remains, which included nursing babies, and the evidence of intense fire use in the cave. Lindqvist also studied the human, seal, pig and fish remains from the Mesolithic layers to consider seasonal versus sedentary occupation, but died in April 2006, before the work was completed.

During the Mesolithic, people were clearly on the island, having arrived by boat. If Stora Karlsö was not a permanent base, where did they spend the rest of the year? Most likely in a camp on the coast of Gotland close to the islands, and there is archaeological evidence of a Mesolithic site close to the 'Pitted Ware' site at Ajvide in Eksta parish (Österholm 1989). Future investigations of Mesolithic sites on Gotland should cast light on the matter of permanent settlement on Stora Karlsö.

\section{Mesolithic-Early Neolithic transition}

There is a discontinuity in the cultural deposits of Stora Förvar between the Mesolithic (9500-8000 cal. BP) and Neolithic layers. AMS dating of bone from younger layers dated to c. 6200-5800 cal. BP indicates an occupation hiatus of about 2000 years. It was observed at the Mesolithic site at Ajvide that the bottom layers had been repeatedly covered by beach deposits (Österholm 1989). This happened at an early stage of the Litorina transgression about 6000 BP, when people lived close enough to the sea so that heavy storms could reach the settlement. Stora Karlsö must have been affected by the transgression, too, and waves probably came very close to the Stora Förvar cave entrance. Small-scale investigations of cultural deposits outside the cave entrance in 1973 uncovered a layer of eel grass (Zostera marina) $22.3 \mathrm{~m}$ above current sea level (a height which corresponds to sea level during the Mesolithic-Neolithic transition) in the northeastern area (Almgren 2007). Eel grass is a common water plant at $2-4 \mathrm{~m}$ depth in the bay outside the cave today (Fredriksson 1976), and it was probably also common in the Litorina Sea. Heavy storms during a transgression could easily have swept masses of eel grass into the cave. The cave is open to northwesterly winds and any wave-swept material would accumulate against the northeastern cave wall. Finds of eel grass from the Mesolithic-Neolithic transition levels at Stora Förvar have been reported previously (Schnittger and Rydh 1940), but were interpreted as the debris from sleeping mattresses.

Thus, during the Litorina transgressions, Stora Förvar could have been an uncomfortable, or even inaccessible, place for habitation. During this time, did people go to mainland Gotland, or did they simply move to parts of Stora Karlsö out of reach of the sea? There is very little evidence for other early settlement areas, although there are reports of early flint artefacts from various locations. Extensive and detailed phosphate mapping might be used to reveal the location of old occupational areas in the future. 


\section{Early Neolithic}

This period is dated from $6000 \mathrm{BP}$ to $5550 \mathrm{BP}$ (Lindqvist and Possnert 1997) and the animal species represented differ from those in underlying layers. Seal bones still dominate, but ringed seal is more abundant than grey seal. Harp seal was also present in small amounts. Different seal species require specialised hunting techniques. The increasing number of ringed seals indicates there was more sea ice in the area as a result of lower winter temperatures. The seals hunted in this period were adult animals rich in blubber as well as meat.

Seal hunting and fishing were undoubtedly the base of the economy, but finds of cattle bone, among the oldest in Sweden, show that domestic cattle was introduced early on Gotland and on Stora Karlsö. Might this also imply permanent settlement? An important issue is the supply of forage in winter. In historic times, sheep have foraged on Stora Karlsö year round, although very cold and snowy winters take their toll. The vegetation in the Neolithic was lush deciduous woodland and grasses, so there was probably sufficient food and firewood for yearround settlement. Did people live in the cave? Charcoal, ash and fireplaces occur in the Stora Förvar deposits in all areas and layers, but they do not necessarily imply year-round living. A common view among archaeologists is that caves are used for temporary shelter, rather than permanent living. It is unclear whether a tent of seal skins on a well-drained terrace was preferable to a damp lodging in a cave with the risk of falling rocks.

\section{Middle Neolithic}

This phase contains characteristic pottery of Pitted Ware culture and dates from $5200 \mathrm{BP}$ to 4000 BP. The Stora Förvar excavations recovered a great number of 'pitted pot sherds'. Österholm (1989) places Stora Karlsö within the resource area of the large Pitted Ware settlement of Jakobs/ Ajvide on the Gotland coast facing the Karlsö islands. As in other Middle Neolithic sites, there is a shift in the animal species represented. Harp seal and ringed seal now outnumber grey seal. The hunting strategy also changed from netting and clubbing to hunting with harpoons. Most of the harpoons found in the cave are from this phase (Clark 1976).

The salinity of the Litorina Sea was higher than in the Baltic today, possibly twice as high (Munthe et al. 1927). The Middle and late-Middle Neolithic coincide with a transgression that had a considerable influence on the Baltic as a whole by producing favourable conditions for marine life (Gräslund 1978). The marine fauna at this time was rich in both species range and population abundance. Species exotic in the Baltic today identified in Stora Förvar include harp seal, killer whale, tuna, gannet and even great auk (Ericson 1989). The gannet is an excellent indicator of the presence of herring shoals. Herring probably occurred in great numbers during this period. The presence of herring in the cave is attested by finds of herring bone in a cave soil sample (Johansson and Larje 1993). The introduction to the Litorina Sea of the other species could be the result of the growth of vast herring populations. Bird life on the island at this time included guillemots, razorbills, gannets and probably the great auk. Tuna, cod and harp seal probably came to feed on the abundance of herring, and killer whales followed to catch the seals.

Again, the question of seasonal or year-round occupation is important. The dominance of sheep is reduced, in favour of pigs, with cattle present in low numbers. Seal hunting and fishing is still important, and bird trapping and egg collecting are other significant sources of protein. But was all this food consumed on the island, or was it 'exported' to a home camp, such as the Ajvide settlement? What about the domestic stock? Could cows, pigs and sheep be left over winter on the island, or were they shipped to and fro? Then there is the question of housing - did people live in caves or build houses? Sea transport was a minor problem, with outrigger 
or double canoes probably used. In tests of replica boats built on Gotland (Österholm 1988), it took two men two hours in a $4.5 \mathrm{~m}$ long outrigger log boat to reach Stora Karlsö from the coast of Gotland. This suggests the people at Ajvide could easily have made short trips to Stora Karlsö.

There is one interesting peculiarity concerning seal hunting and fishing in the Middle Neolithic. In most coastal settlements on Gotland, harp seal is the most common catch, but on Stora Karlsö, the ringed seal is dominant. In addition, the cod from Karlsö were larger than the ones from Ajvide. Lindqvist and Possnert (1997) present various scenarios to explain this, but there were clearly environmental differences between Stora Karlsö and Gotland.

\section{The Bronze Age}

This period in the prehistory of Stora Karlsö is still poorly known. Bone in the upper layers in Stora Förvar is dominated by remains of domestic cattle, mostly sheep and goat with a few remains of domestic fowl. The number of seals and pigs decreases. The function and importance of the cave appears to change, coinciding with the appearance of stone cairns built around the island.

\section{Röjsu}

On the highest point of the eastern part of the island, $51.6 \mathrm{~m}$ above sea level, is a large cairn. Fineman identified it on his 1725 map and mentioned that a tree was growing inside that could be seen from far away (Jacobson 2005). Linnaeus (1745) also noticed the mound and the single tree on his visit to Stora Karlsö in 1741. The tree and the cairn provided an excellent navigation mark for seafarers. The cairn was called 'röjsu', which simply means 'cairn'. The tree associated with the cairn (an ash) survives today.

Röjsu was examined but not fully excavated in 1889 when Fredrik Nordin (1889) excavated most of the prehistoric cairns and monuments on the island during a summer season. His report recorded 51 monuments. Röjsu has a diameter of $28 \mathrm{~m}$, a height of $2.5 \mathrm{~m}$ and was built from limestone slabs and boulders, with smaller stones used in the filling. Nordin noticed that an irregular hollow was already dug out around the tree and found inside the cairn a fairly evenly built wall, parallel to the diameter of the cairn and $1.6 \mathrm{~m}$ high. A trench was opened from the southwest into the cairn centre, at the bottom of which he found the frontal part of a human skull and some other human bones. The only artefact found was a small pointed object made of slate. Rydh (1931) dates the cairn to the Early Bronze Age (3750-3050 BP), based on the presence of non-burnt human bones. In the Late Bronze Age, cremation became the preferred burial custom.

\section{Lauphargi}

In a less-elevated, but nevertheless conspicuous, location in the southwest is another large Bronze Age cairn, called Lauphargi (Figure 3), which was probably also used as a navigation mark. The cairn has a diameter of about $25 \mathrm{~m}$ and the intact southwestern part stands about $4 \mathrm{~m}$ above the ground. The description by Nordin (1889) records a $1 \mathrm{~m}$ high wall built of limestone slabs in better condition than the one in Röjsu. Nordin thought the cairn had been plundered and the interior disturbed, as he found displaced large slabs that might have belonged to a stone cist. A stone cist indicates a date in the Early Bronze Age, as for Röjsu, but no human remains were found, only large numbers of pot sherds and a few burnt bone fragments spread over a $5 \mathrm{~m}$ wide area. With no datable finds, there is a dating problem. But if the large slabs were not from a stone cist, the finding of a cremation suggested by the unidentified burnt bone would place the cairn in the Late Bronze Age. 


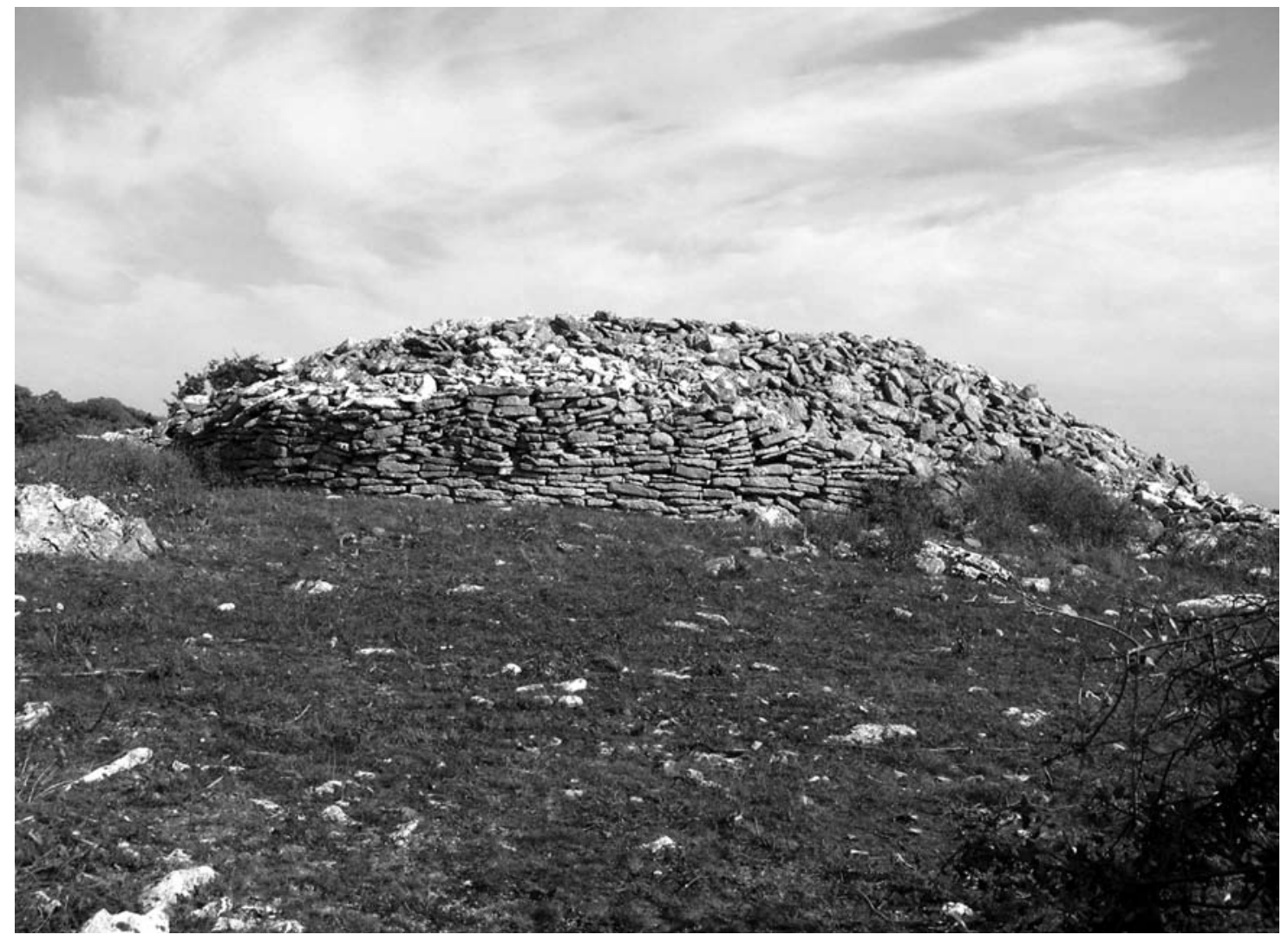

Figure 3. Lauphargi, the undamaged west wall (photo by R. Larje).

\section{Smaller cairns}

Northeast of Lauphargi on the hillside there are two more smaller cairns, believed to be from the Bronze Age. The largest has a diameter of $8 \mathrm{~m}$ and contained some bones (not burnt), and the smaller one, with a diameter $4 \mathrm{~m}$, contained a ceramic vessel with some burnt bone fragments. The elevated location of the cairns is consistent with the Bronze Age, but the structures have not been absolutely dated. The ceramic vessel in the smaller cairn is of an uncommon type and probably dates to the Late Bronze Age.

Only a few of the c. 400 large Bronze Age cairns on Gotland have been scientifically investigated, but it is clear the large cairns are more than just heaps of stones. Interesting details include the presence of a tower-like construction in the interior, built from horizontally placed limestone slabs, and inside this tower a cist with a compact lining of stone slabs, found in cairns at Hau in Fleringe and at Kauparve in Lärbro, both in the northern part of Gotland (Lindquist 1979). Nordin (1889) noticed well-constructed walls in Röjsu and Lauphargi, but judged the interior had been disturbed in both cases. In the autumn of 2007, all of the vegetation in and around Lauphargi was removed. Traces of the interior wall were visible around most of the cairn. There is also a slab-wall construction, which could be taken for a cist. The larger slabs thrown about might have been a roof covering. Obviously, we have two kinds of Bronze Age graves on the island; larger with inner walls, and smaller without inner walls.

Four Bronze Age cairns on the tiny island suggest it was an important place strategically or culturally. The construction of the large cairns was not an easy enterprise; they required social and economic investment in labour.

It should be noted that the Bronze Age cairns were excavated during a hectic summer season in 1889 which also included the excavation of all the other stone mounds on the island. Unfortunately, no details were published by Fredrik Nordin, the archaeologist in charge, except 
for a short field report. In 1931, Hanna Rydh examined Nordin's report and the artefacts in a chapter on the Bronze Age on Stora Karlsö. She included items such as an Early Bronze Age knife from Stora Förvar and a well-preserved Late Bronze Age spear head found by Willy Wöhler reportedly wedged into a cliff wall. No identification of the bone was done and the material is now almost certainly lost.

\section{The Iron Age}

\section{Graves}

On a beach ridge at the northern harbour there are seven white, shiny mounds of limestone (Figure 4) marking the graves of Iron Age people. There are about 60 Iron Age stone sites on Stora Karlsö. Nordin's earlier report included information about the size and internal construction of the tombs, the orientation of burials, and grave goods. Information about the Iron Age of the island was compiled by Rydh (1931). Some graves could be dated from accompanying artefacts to the Early Roman-Migration Period (200-400 AD). No osteological identification was done, and today, much of the bone material has been lost or mixed so that individual bones cannot be linked with a particular grave.

\section{Human remains}

An attempt was made by Sundeen (2005) to establish the status of the human bone recovered by Nordin, but it soon became clear that not all of the remains were from Iron Age burials. A ${ }^{14} \mathrm{C}$ dating on three thigh bones gave ages of $95 \pm 40 \mathrm{BP}, 525 \pm 40 \mathrm{BP}$ and $160 \pm 40 \mathrm{BP}$. None of these individuals were from the Iron Age. There are at least two recent inhumations in the Nordin material and the individual dated to $525 \pm 40 \mathrm{BP}$ might have been a worker from the 17 th

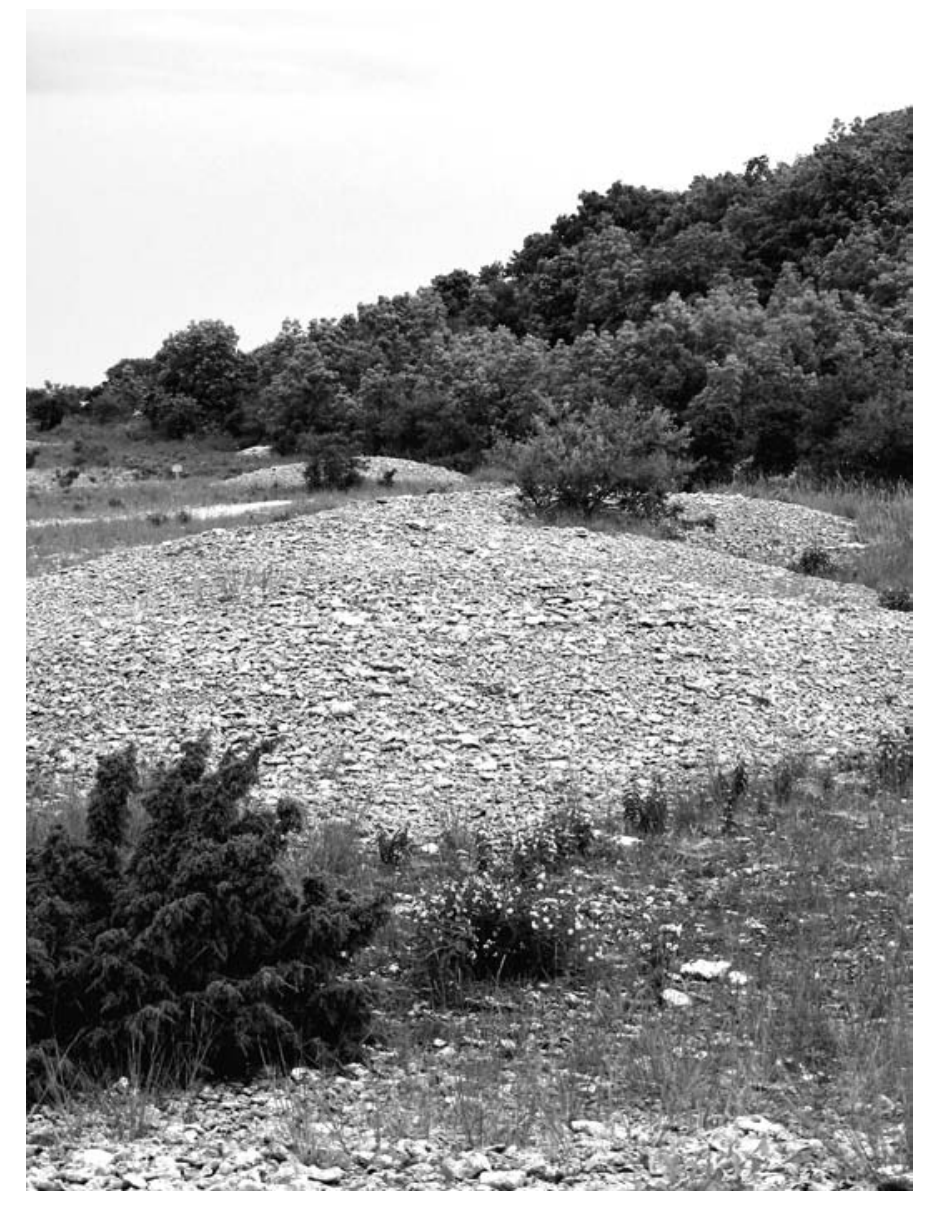

Figure 4. Iron Age graves on a beach ridge in the north (photo by R. Larje). 
century stone quarry. One skeleton was found high up in a small cairn, with a stone sinker with initials in Latin letters. Finding relatively recent graves on Stora Karlsö is not uncommon. One skeleton believed to be from a body swept ashore on the island can be seen in a hollow covered with slabs on the eastern rocky shore, and parts of another probably recent skeleton were found in a rock shelter by the author in September 2007 (Jacobsen and Larje 2008).

Despite the complicated situation regarding the age of the remains, an analysis was done on the human bones that, from the Museum of National Antiquities inventory number, were judged as deriving from the 1889 investigations.

Nordin believed most of the individuals found in the burials were males. Sundeen (2005) found that in general, male characteristics were predominant in all skeletal elements examined. A calculation based on the maximum length of eight right femora gives a mean stature of $173.6 \mathrm{~cm} \pm 3.94 \mathrm{~cm}$, which corresponds well to Nordin's field observations that the buried individuals were tall, around $170 \mathrm{~cm}$. Sundeen (2005) also tried to assess the age distribution of the remains, based on dental attrition and tooth eruption, judging most individuals to have been quite young, nine aged from 17 to 25 , and 10 aged from 25 to 35 , with only one older than 35. The osteological investigation recorded healed injuries and patterns of bone wear consistent with hard physical activity.

\section{Graves re-used}

Some graves contained two bodies, either laid out beside each other, or with one burial on top of the other - the grave having been re-used on a later occasion. There is evidence of successive use in two graves. Both were round stone settings with a diameter of about $10 \mathrm{~m}$ and a height of $80-90 \mathrm{~cm}$. About $20 \mathrm{~cm}$ down, a secondary burial was found in a stone cist, aligned northeastsouthwest, with the head to the southwest. Underneath the grave was a primary burial, not in a cist, and in an opposite orientation, with the head to the north. The primary inhumation at the bottom of the grave was dated to the Migration Period (AD 400 to AD 800), while the secondary inhumation was thought to be from the Viking Age.

\section{Square stone settings}

Twelve graves were considered to be cremation graves, from the number of burnt bone fragments and abundant wood ash, and in some cremations there had been a secondary inhumation. Two cremation graves are particularly impressive. On the slope of the Litorina ridge in the north are two square stone settings beside each other, both with compact stone layers (Figure 5). Nordin noticed a thick layer of ashes and charcoal, with some fragments of burnt bone in the western setting, which measured $9 \mathrm{~m} \times 9 \mathrm{~m}$. The eastern setting, measuring $7 \mathrm{~m} \times 7.7 \mathrm{~m}$, contained an unusual deposit. Close to the centre and under a limestone slab was a miniature stone cist with a pot inside. The pot contained cremated bones and a scabbard chape of iron. Covering the pot was a shield buckler and a deliberately bent and broken spear head (Rydh 1931). The two quadrate stone settings were dated to about AD 0, and are the earliest Iron Age graves on the island. The grave type is well known in Sweden, but not on Gotland.

\section{Search for the living population}

Although only a few graves could be dated with certainty, most of the 50 or so stone settings are believed to span the Early Roman-Migration Period. The number of graves represents a sizable population. Where are the traces of the living people? In 1973, a test investigation was made of the remaining cultural layer outside the Stora Förvar cave, to check the stratigraphy and to map the thickness of the soil that had been cleaned out from the cave during excavations. Some surprising finds were made in the dumped soil, most spectacularly a number of Viking Age 


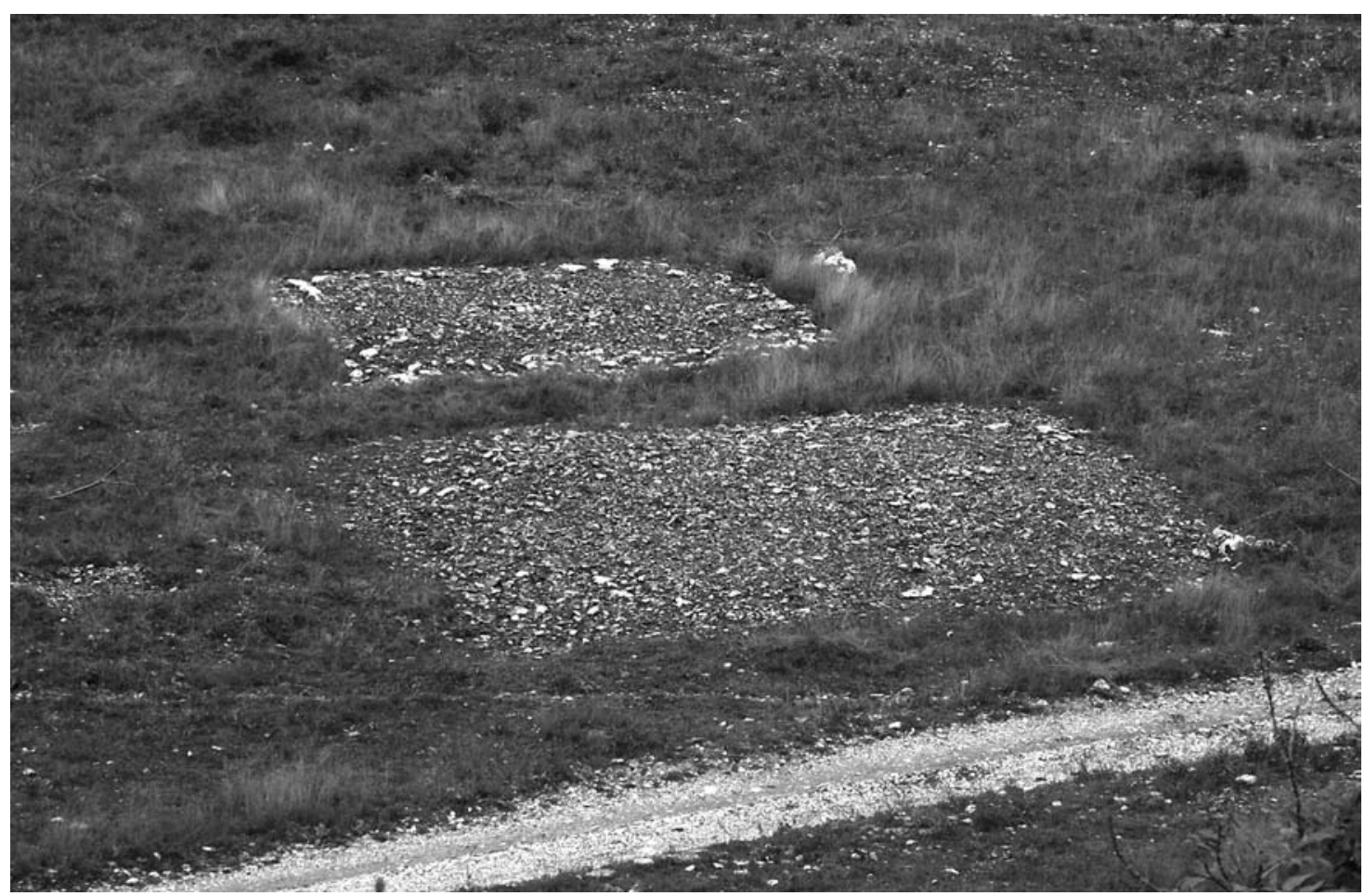

Figure 5. The two square stone settings on the northern plain (photo by R. Jacobson).

moulds for making brooches, of types also made on Gotland and on the Swedish mainland. A pilot investigation of areas with high phosphate values was made in 1974. Between 1975 and 1981, three trenches were excavated in an area with high phosphate values. Excavations revealed traces of small-scale metallurgic production. Among the finds were a Roman silver coin, two Roman Iron Age bronze weights, and a piece of payment gold in the form of a spiral ring (Almgren-Aiken 1976, 1979, 1980). From the excavated finds, Almgren-Aiken suggested Stora Karlsö might have been a convenient resting place on the sea journey to the Swedish mainland, Öland or other places on Gotland, or some kind of free-trade port. The idea has merit. The northern bay is a sheltered landing and is also a good harbour.

Boat graves?

The free-trade-port idea brings us to unusual monuments in the northern and southern harbour area. On a beach ridge in the north are 12 depressions, about $20 \mathrm{~m}$ long and oriented vertically to the beach (Figure 6). Inspired by the excavation of boat-grave sites in Uppland in Sweden in 1928, Rydh suspected the depressions to be similar grave types, and not landing places for boats. Nordin had opened a trial trench in one wall, but had found nothing. Rydh made a complete excavation of one depression and found her suspicion was correct - the boat graves of the 'Valsgärde' type were a new type of grave for Karlsö. Rydh found traces of an area that had been dug out for a wide but shallow boat, $9 \mathrm{~m}$ long, $4 \mathrm{~m}$ broad and about $75 \mathrm{~cm}$ from 'keel to rail'. The stem was $7 \mathrm{~m}$ above sea level and the stern was $6 \mathrm{~m}$ above sea level. Only a few boat rivets were found, along with a heavily corroded iron knife, a blue glass pearl and a great variety of bones. The few and fragmentary human remains were from two individuals and the large quantity of animal bones represented several cattle, sheep or goat, horse, pig, seal and one bone from a dog. The cattle and pig bones had cut marks, but the bones and artefacts were spread out in no particular order in the boat, except for a concentration towards the stern.

A trench through another depression gave a similar result. Human bone from two 


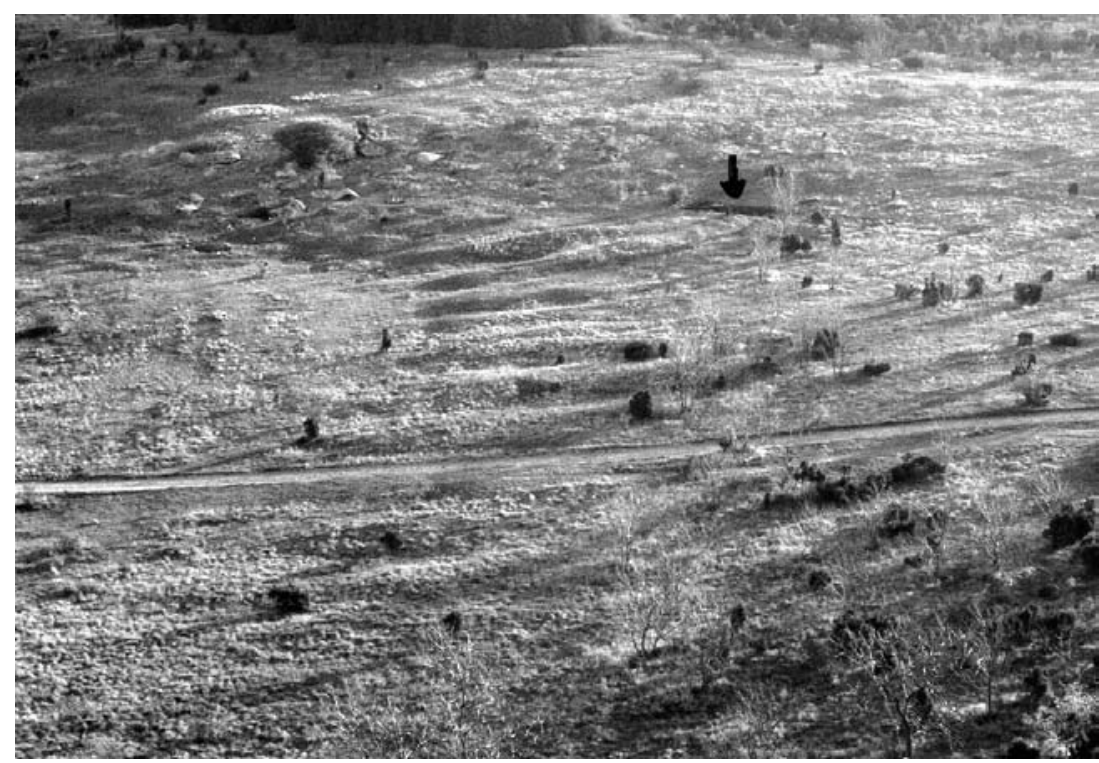

Figure 6. 'Boat-shaped' depressions in the northern plain. The arrow indicates a trench opened during the 1975-1981 excavations (photo by R. Jacobson).

individuals was found, along with the disturbed remains of cattle, sheep, horse and seal. The artefacts included a rivet plate, a yellow ceramic pearl and amber dice. A hole excavated in a third depression had similar types of animal bones and an iron nail. The six depressions and banks of stone rubble on the south plain were not investigated, but a spade hole in one uncovered a horse tooth, interpreted to be prehistoric.

Rydh (1931) dated what she believed were certainly boat graves to the Viking Age. But was she right? The current interpretation of the depressions is that they are boat landing constructions, but the human remains definitely indicate burial use. Two stone settings on the same beach ridge contain secondary graves probably from the Viking Age, so there is reason to believe in a succession of Viking inhumations to the west. This means the boat-landing constructions might be considerably younger, and were therefore further away from the shoreline, and so not comfortably accessible. The interpretation of the depressions is still open, requiring further fieldwork (Figure 7).

\section{The Middle Ages}

\section{Graves}

On the northern plain is a 'cemetery' surrounded by an oval stone setting. In it, Nordin found six burials and a few artefacts, all with medieval features. Another, even larger, irregular oval stone setting, popularly described as a Christian cemetery, is under the hill slope in the south. There, Nordin (1889) found a skeleton under a 'pile of stones', but Rydh, although she opened several trenches, only found sheep bones, which gave her reason to assume the construction was a sheep pen containing human remains from someone who was buried in secrecy. There is also a small cairn in the southern plain, with medieval features and a primary burial.

\section{Stone quarries}

The 13th century boom in church-building on Gotland created a demand for the decorative red, fossil-rich limestone from Stora Karlsö, the 'Karlsö marble'. The layered rock could be quarried into pillars and lintels and other decorative elements. The quarrying technique in the 
Middle Ages made use of the properties of the rock. A row of palm-sized holes was chopped into the cliff. Dry oak wedges were driven into the holes and then soaked with water, swelling them and causing the limestone to split (Ohlsson 1960) (Figure 8). The raw material was loaded on to boats, probably from the southern shore, and shipped to Gotland for working and finishing. The Middle Age quarries were used for about 100 years. They were reopened in the 17 th century, when drill holes and gunpowder were used to extract blocks. There is a written record from September 24 1605, that 'Karlsö marble' was exported to Denmark in an order for 37 stone elements from the island, to be collected by a royal ship (Jacobson 2005). The 17th century quarrying was probably not very extensive, and we can assume the quarries today look the same as when they were abandoned.
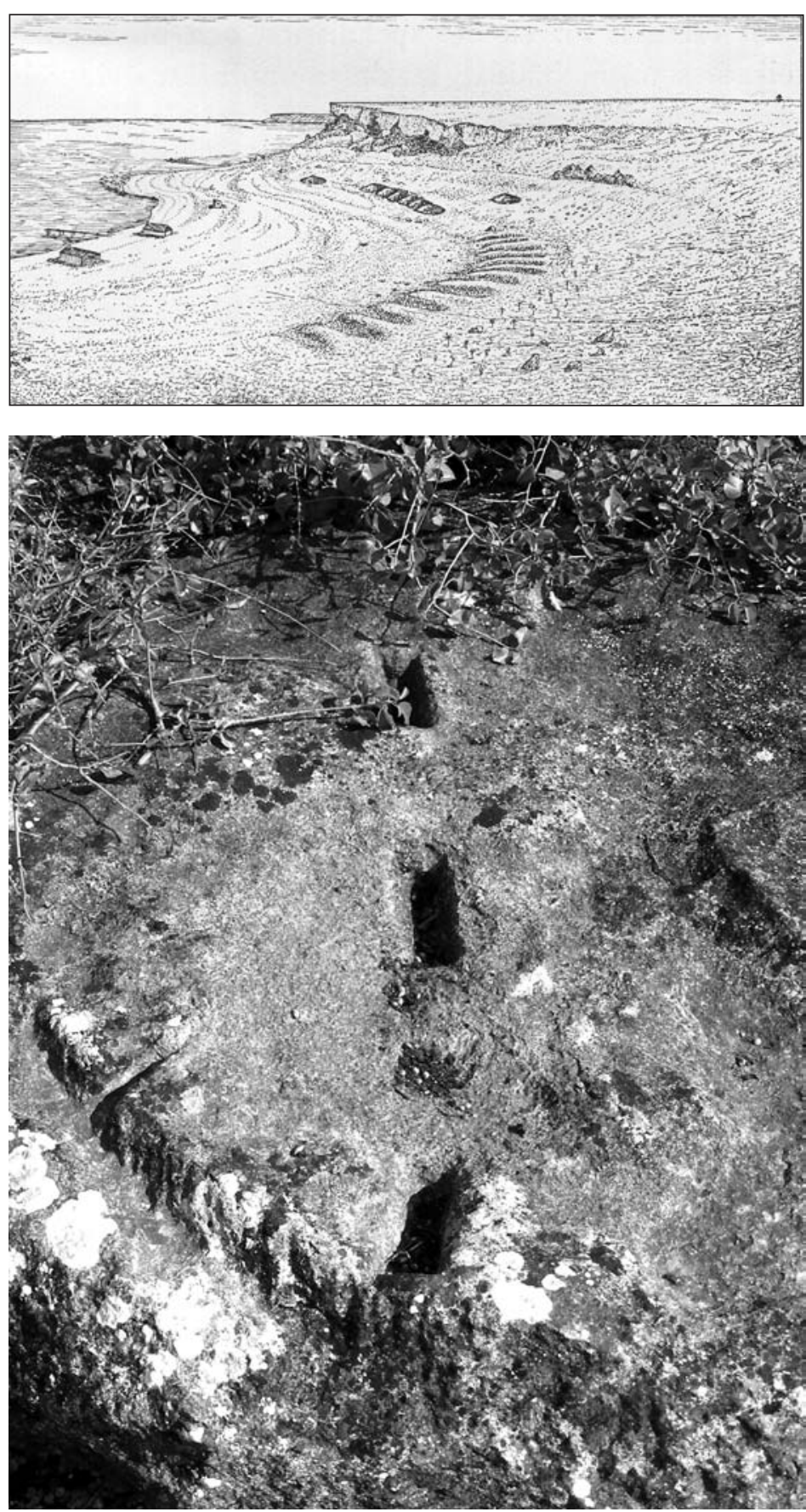

Figure 7. Ink drawing by H. Faith-Ell (1930) of the Iron Age graves and 'boatshaped' depressions. At top right is the single ash-tree at Röjsu, the Bronze Age cairn (from Rydh 1931).
Figure 8. Remains from the stone quarry used in the Middle Ages (photo by R. Jacobson). 
In the event of a fatal accident to a stone worker, the corpse was almost certainly brought back to Gotland for burial in the local churchyard. But the quarry on Stora Karlsö could have attracted people from more distant areas of the Baltic, too far away to send a body to. A grave on Karlsö would have been a natural alternative.

\section{Conclusion}

Some important pieces are missing from Stora Karlsö’s prehistoric jigsaw puzzle. In the Mesolithic and Neolithic, people were on the island and used many of its wild food resources. But was the occupation permanent or seasonal? Either way, I favour the well-drained and sheltered terraces away from Stora Förvar cave as the main dwelling site during the early period. In the Bronze Age, Stora Karlsö was obviously significant, given the construction of four cairns. Where do we find evidence of the community which had an interest in the island and the economic means to build such impressive symbols of ownership? Who built the square stone-setting graves, so rare on Gotland but more common on the Swedish mainland? The great number of Roman Iron Age-Migration Period graves suggests a reasonably large population on the island. It is possible that at this time, Stora Karlsö was a trade port and had a permanent community. The graves might also have functioned as land-ownership markers. Might there have been another port on the southern shore, where there are also graves?

What role did the island play in the Viking Age? Can new excavations unmask the true nature of the 'boat graves'? The Vikings in the Baltic were traders and Stora Karlsö was on the route from Gotland to southern Scandinavia. We only have glimpses from this period, glimpses of a connection with the Swedish mainland and even Norway (Zachrisson 2006).

The 'Karlsö marble' quarries, untouched since the 17 th century, are waiting to be documented, including the location of stone-worker lodgings. A study of the quarry should also include an analysis of the churches on Gotland containing red marble to establish whether the construction material was restricted to churches in particular areas, or whether it was used more widely.

\section{References}

Almgren-Aiken, E. 1979. Stora Karlsö - rastplats eller frihamn? Arkeologi på Gotland (1979):169-172.

Almgren, E. 1976. Utgrävningen i Norderhamn. In Stora Karls en presentation, Karls Jagt- och Djurskyddsförenings AB, pp. 13-15, Visby, Gotland.

Almgren, E. 1980. Utgrävningar på Stora Karls. Gotländskt Arkiv (1980):121-122.

Almgren-Aiken, E. 2007. Rapport rörande provundersökning av kulturlager utanför grottan Stora Förvar, Stora Karlsö I:3 Eksta sn. Gotland.

Clark, J.G.D. 1976. A Baltic Cave sequence: A further study in bioarchaeology. In H. MitschaMärheim, H. Friesinger and H. Kerchler (eds), Festschrift für Richard Pittioni zum siebzigsten Geburtstag. Archaeologia Austriaca 13:113-123.

Ericson, P. 1989. Faunahistoriskt intressanta stenålderfynd från Stora Karlsö. Fauna och flora 84:192-198.

Ericson, P.G.P. and A. Knape 1990. Stora Karlsö - en jaktstation under neolitisk tid. Gunneria 64:197-205.

Eriksson, J.A. 1988. Stora Karlsös vegetationshistoria. Gotländskt arkiv (1988):19-30.

Eriksson, J.A. 1992. Natural History of Xerotherm Vegetation and Landscapes on Stora Karlsö, an Island in the Western Baltic Basin, Sweden. Striae 35, Uppsala. 
Fredriksson, G. 1976. Alger och vattenförhållanden kring Stora Karlsö, In Stora Karlsö, en presentation, pp. 35-47. Visby: Karlsö Jagt-och Djurskyddsförenings AB.

Gräslund, B. 1978. Sill och sillfiske i Östersjön under stenåldern. Tor 17:57-64.

Jacobson, R. 2005. Om ett par gamla Karlsökartor och lite till. In R. Jacobson and R. Larje (eds), Stora Karlsö - människor, verksamheter och händelser kring en ö, pp. 162-171. Visby: Ödins förlag AB.

Jacobson, R. and R. Larje. 2008. Slumpfunna skelettfynd på tidernas ö. Karlsöbladet 1:4-8.

Jacobson, R. and R. Larje nd. Neighbours in Vinglu. New skeletons on Stora Karlsö. Unpublished report in possession of the author.

Johansson, B.M. and R. Larje 1993. A 100 year old soil sample from Stora Förvar. Refuse or Potential Resource? Pact 38-III(3):297-301.

Knape, A. and P. Ericson 1988. Stora Förvar - kontinuitet och förändring i ett resursutnyttjande. Gotländskt Arkiv (1988):31-38.

Lindquist, M. 1979. Storrösen In Arkeologi på Gotland (1979):33-42.

Lindqvist, C. 1996. Gotländska stenåldersstudier I, De äldsta säljägarna på Gotland. Benbiten 9(3):7-13.

Lindqvist, C. and G. Possnert. 1997. The subsistence economy and diet at Jakobs/Akvide, Eksta parish and other prehistoric dwellings and burial sites on Gotland in a long-term perspective.

In G. Burenhult (ed), Remote Sensing, vol. 1. Theses and Papers in North-European Archaeology 13:a:29-90.

Linnaeus, C. 1745. Öländska och Gothländska Resa-förrättad år 1741. Stockholm och Uppsala (Senare upplagor finns).

Munthe, H., J.E. Hede and L. von Post 1927. Beskrivning till kartbladet Hemse. Geologiska Undersökning, Ser. Aa Nr 164.

Ohlsson, E.W. 1960. Nagra anteckningar om Stora Karlsö under medeltiden och nya tiden fram till àr 1880. Gotland: Visby.

Österholm, I. 1989. Bosättningsmönstret på Gotland under stenåldern. En analys av fysisk miljö, ekonomi och social struktur. Theses and papers in archaeology 3. Stockholm: Stockholm University.

Österholm, S. 1988. I utriggarkanot över Östersjön'. Populär Arkeologi. Årgång 6(2):26-30.

Pira, A. 1909. Studien zur Geschichte der Schweinerassen, insbesondere derjenigen Schwedens. Zoologische Jahrbuecher Supplement X:1-192.

Pira, A. 1926. On bone deposits in the cave'Stora Förvar' on the Isle of Stora Karlsö, Sweden. Acta Zoologica 7:123-217.

Retzius, G. 1890. Om de i grottan Stora Förvar funna menniskokranierna. Ymer 10:286-287.

Roos, A. 2000. Sälliv. Stockholm: BonnierCarlsen.

Rydh, H. 1931. Stora Karlsö under forntiden. Stockholm: Karlsö Jagt-och Djurskyddsförenings Aktiebolag.

Schnittger, B. and H. Rydh 1940. Grottan Stora Förvar på Stora Karlsö undersökt av Lars Kolmodin and Hjalmar Stolpe. Stockholm: KVHAA.

Storå, J. 2006. Om den förhistoriska bosättningen på Stora Karlsö i skelettfyndens ljus. Karlsöbladet 2:5-8.

Sundeen, H. 2005. Benen från Stora Karlsö. En analys av skelettmaterialet från Fredrik Nordins utgrävning 1889. CD-uppsats, Högskolan på Gotland.

Zachrisson, T. 2006. Hägringen och fornborgen, Stora Karlsö under järnåldern. Karlsöbladet 2:9-12. 